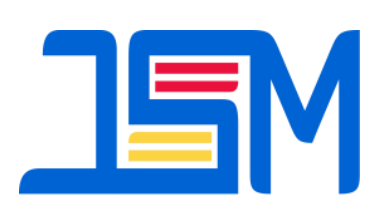

JAMBURA SCIENCE OF MANAGEMENT

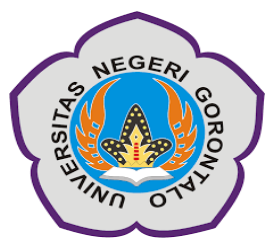

\title{
The Importance Of Work Life Balance To Improve Work Satisfaction
}

\author{
Nasution Nasution ${ }^{1}$, Mohamad Ali $i^{2}$ \\ ${ }^{1,2}$ Department of Human Resource Management, Sekolah Tinggi Ilmu Ekonomi Bima, Nusa \\ Tenggara Barat, Indonesia \\ Monginsidi Street, Bima City, Telp. (0374)42556 \\ E-mail:nasution.stiebima16@gmail.com; muhalialparady@gmail.com
}

\begin{abstract}
:
Work-Life Balance as an independent variable consists of three indicators of balance, namely the balance of time, the balance of involvement and the balance of satisfaction. The job satisfaction as a dependent variable is divided into four factors, namely psychological factors, social factors, physical factors and financial factors. This study aims to determine the effect of Work-life balance on employee Job Satisfaction at the Bima Regency Social Service. This type of research uses causal quantitative methods with primary data sources obtained from interviews and questionnaires distributed to 60 respondents. The sampling technique used is simple random interconnection with the Slovin formula. The analytical tool used is the validity and reliability test, simple linear regression, correlation coefficient, coefficient of determination and T-test. The results of this study indicate that Work-life balance has a significant effect on job satisfaction of Bima Regency Social Service employees. This can be seen from the significant value of $0.000<0.05$.
\end{abstract}

\section{Keywords: Work-life balance; Job satisfaction}

Employees are an asset for the agency / company. Employees play the main role in running the life of the organization. To achieve a goal in the agency required adequate Human Resources (HR), which is in accordance with the requirements in the agency, and also must be able to carry out the tasks that have been determined. If employees have high productivity and work motivation, it will produce good performance and achievement for the organization. In maintaining employee performance in order to remain productive it is necessary to pay attention to job satisfaction with employees. When a person feels satisfaction in working, of course he will try as much as possible with all the ability he has to complete his work assignments. Thus the productivity and work results of employees will increase optimally. Job satisfaction is a pleasant emotional state or general attitude towards differences in the rewards received and those that should be received. Job satisfaction is influenced by several factors, namely fair and proper 
remuneration, placement in accordance with expertise, severity of work, work environment and atmosphere, equipment that supports work performance, leadership and leadership attitudes and monotonous or non-work nature of work. Basically job satisfaction is an individual thing because each individual will have different levels of satisfaction according to the characteristics that apply to him. The issue of job satisfaction is very important to note, because high satisfaction will create a pleasant work atmosphere and will encourage employees to excel.

There are many factors that can affect job satisfaction. These factors provide different job satisfaction depending on the individual employee. According to Sutrisno (2015: 80) factors that influence job satisfaction are: (a) Psychological factors, are factors related to employee psychology, which include interests, tranquility in work, attitudes towards work, and skills. (b) Social factors, are factors related to social interaction between employees and employees with superiors. (c) Physical factors, are factors related to the physical condition of employees, including the type of work, setting the time and rest time, work equipment, the state of the room, temperature, lighting, air exchange, employee health conditions, age. (d) Financial factors, are factors related to employee insurance and welfare, which include the system and the amount of salary, social security, types of benefits, facilities provided, promotions.
Job satisfaction is a form of emotional attitude that is fun and loves the work which is shown by work morals, discipline, and work performance. According to Hasibuan (2015: 39) indicators of an employee's job satisfaction can be seen from the following matters: (1) Satisfaction of the job, meaning that if all the needs of a person to work are fulfilled either from the materials needed or from a supportive environment then job satisfaction will occur. (2) Satisfaction with the rules and attitudes of the culture superiors as well as the characteristics that exist in the organization, which if the rules in carrying out work can support the work, employees will feel job satisfaction. (3) Satisfaction with colleagues means that job satisfaction will arise if in an organization there is a good relationship. Satisfaction with promotion, where there is an opportunity to get an award for one's work performance, where he is given a higher position and assignment and is accompanied by a salary increase. This promotion greatly affects job satisfaction can be appreciated by increasing its position accompanied by the salary to be received. (5) Satisfaction with Salary / Compensation means compensation from work that is balanced with the work he has done.

An employee's job satisfaction in an organization cannot be separated from career development, and work-life balance. The balance between personal life and work life is called work-life balance. Work-life balance is a balanced state in two demands where the work and life of an 
individual are the same. Work-life balance in the view of Bima Regency Social Service employees is the choice of managing work and personal obligations or responsibilities towards families. Whereas in the view of organizational work-life balance is a challenge to create a supportive culture where employees can focus on their work while at work.

Work life balance itself is how one is able to balance work demands with personal and family needs (Ramadhani, 2013). Creating and maintaining employee job satisfaction is an effort that can have a major impact on the survival of an organization. This is because, satisfied employees bring positive effects to the organization, such as increasing efficiency and productivity. In an effort to increase job satisfaction, it is better to apply worklife balance, because it is very important for organizations to realize that employees not only face roles and problems in work, but also outside of work.

In order to maintain the quality and commitment of employees who are required to achieve the targets given, the Bima Regency Social Service is currently implementing a Work-Life Balance program. According to Frame and Hartog in Moedy (2013) work-life balance means employees can freely use flexible work hours to balance their work or work with other commitments such as family, hobbies, arts, studies and not just focus on their work. Then according to Moore in Moedy (2013) a good work-life balance is defined as a situation where workers feel able to balance work and personal life or other commitments.

The core of this program is a concept of moral intelligence and motivation that will create a balance in work, self-management, self-motivation, and responsibility. The purpose of this program is expected to create a better quality of life which will create a healthy and fit body, clear thinking, a sincere body and a sense of enjoyment of life. High expectations with the implementation of the Work-Life Balance program, the employees of the Bima Regency Social Service not only spend time just for work, but also have other lives outside the world of work, such as in the family, social life, so as to create a balance, which will make them happy and satisfied at work.

By realizing the importance of the role of human resources, organizations must utilize human resources as effectively as possible in order to have good performance, one of which is by providing Work Life Balance. According to Lockwood (2013) work-life balance is a balanced state in two demands where the work and life of an individual are the same. Where work-life balance in the view of employees is the choice of managing work and personal obligations or responsibilities towards the family. Thus the writer can conclude that work-life balance is the extent to which an individual is bound together in work and family, and are equally satisfied with the role at work and the role in the family.

Another understanding of worklife, according to Purwati (2016), is that 
the employee will be able to work in a flexible manner and use it with a lot of commitment and use it on commitments. This is consistent with research conducted by Fenia Annamaria Rondonuwu, et al (2018) which shows that Work Life Balance has a significant effect on employee job satisfaction at Manado Sintesa Peninsula Hotel.

Work life balance has a good content at work and also outside of work with a minimum of conflict (Clark in Fapohunda, 2014), this work life balance, about how a person seeks balance as well as comfort at work and outside of work. Rāmadhani (2013) is found in three aspects in a great work-life, namely: (1) Time Balance, which involves the amount of time given to work and activities outside of work. (2) Involvement Balance, which is the level of psychological involvement and commitment at work or outside of work. (3) Satisfaction Balance is related to the level of job satisfaction at work and things outside of work.

\begin{tabular}{|l|l|}
\hline $\begin{array}{l}\text { Word-Life Balance }(\mathbf{X}) \\
\text { 1.Time balance, } \\
\text { 2.Balance of } \\
\text { involvement } \\
\text { 3.Balance of satisfaction }\end{array}$ & $\rightarrow$\begin{tabular}{l} 
Work Satisfaction $(\mathbf{Y})$ \\
1.Psychological factors \\
2.Social factors \\
3.Physical factors \\
4.Financial factors \\
\hline
\end{tabular} \\
\hline
\end{tabular}

Figure 1. Conceptual Model

\section{METHOD}

\author{
This research is a quantitative \\ study using a causal method. The \\ instrument used in this study was a closed
}

Work life balance occurs when employees can balance personal activities with work to be done, so that employees can minimize conflicts that might arise if employees cannot spend quality time on personal matters or work activities. The relationship between the two variables can be seen from the connection aspects of work life balance related to job satisfaction. (Fisher, Bulger and Smith (2011). The theory is in accordance with the results of research conducted by Qodrizana, (2015), Ganapathi (2017), and Schermerhon (2012), The Effect of WorkLife Balance on Job Satisfaction (Study of Female Employees at the Insan Permata Tunggulwulung Foundation in Malang). shows that Work-Life Balance has a significant effect on Job Satisfaction.

Based on the description above, this paper was made with the aim to find out the importance of work life balance to improve work satisfaction with the conceptual model as shown below:

\section{Work Satisfaction (Y) \\ 3.Physical factors \\ 4.Financial factors}


a tip value that states strongly agree and strongly disagree. This study involved 60 respondents who were employees of the Bima Regency Social Service, the amount of which was obtained using the Slovin formula. Samples were selected using simple random sampling technique. The analytical tools used is validity test, reliability test, simple linear regression, correlation coefficient, coefficient of determination and significant test (t-test).

\section{RESULT}

\section{Validity and Reliability Test}

The results of the validity test of each statement submitted in the questionnaire to respondents showed that all items of the statement in the questionnaire were declared valid because the value of $r$ product moment $>r$ table at the $5 \%$ significance level, then all items of the Work Life Balance variable statement and the variable Work satisfaction were declared valid. This means, there is no data that is invalid / missing. Thus the entire number of indicators can be used in this study. Reliability testing uses the Cronbach Alpha formula by testing the level of reliability (reliability) of each variable questionnaire. The reliability test results show that the Cronbach's Alpha variable Work Life Balance is 0.780 and the Cronbach's Alpha value of job satisfaction variable is 0.880 so that it is declared reliable where the value is higher than the minimum value of Cronbach's Alpha which is 0.6. Thus the data obtained in this study are suitable for use in the following analysis.

\section{Simple Linear Regression}

Based on research data collected for both the dependent variable (Y) and the independent variable $(\mathrm{X})$ processed using the SPSS 23.0 program, the simple linear regression calculation results are as follows:

\section{Table 1. Simple Linear Regression Test}

Coefficients $^{\mathbf{a}}$

\begin{tabular}{|c|c|c|c|c|c|}
\hline \multirow[b]{2}{*}{ Model } & \multicolumn{2}{|c|}{$\begin{array}{c}\text { Unstandardized } \\
\text { Coefficients } \\
\end{array}$} & \multirow{2}{*}{$\begin{array}{c}\text { Standardized } \\
\text { Coefficients } \\
\text { Beta }\end{array}$} & \multirow[b]{2}{*}{$\mathrm{t}$} & \multirow[b]{2}{*}{ Sig. } \\
\hline & B & Std. Error & & & \\
\hline $1 \quad$ (Constant) & -1.719 & 2.285 & & -.752 & .455 \\
\hline $\mathrm{X}$ & 1.062 & .067 & .901 & 15.827 & .000 \\
\hline
\end{tabular}

a. Dependent Variable: Y

Source: Data processed (SPSS, 23.0)

From the results of the simple linear regression test above, the regression equation can be made as follows: $\mathrm{Y}=$ $1,719+1,062 \mathrm{X}$
It is known that the Work-life Balance (X) variable shows a positive regression coefficient value, it shows the positive direction or direct relationship of the Work-life Balance (X) variable with 
employee satisfaction (Y). This can be interpreted that if the better the provision of Work-life Balance (balance of time, balance of involvement and balance of satisfaction), then employee satisfaction will be even greater, and vice versa if not implemented Work-life Balance, then employee job satisfaction will decrease.

\section{Correlation coefficient}

Product moment correlation test is used to determine the relationship between two variables expressed in one index. The results of the correlation coefficient test on research variables are as follows:

Table 2. Correlation Coefficient

Model Summary

\begin{tabular}{|l|l|r|r|r|}
\hline Model & $\mathrm{R}$ & $\begin{array}{c}\mathrm{R} \\
\mathrm{S}\end{array}$ & $\begin{array}{c}\text { Adjusted } \\
\text { R Square }\end{array}$ & $\begin{array}{c}\text { Std. Error } \\
\text { of the } \\
\text { Estimate }\end{array}$ \\
\hline 1 & $.901^{\mathrm{a}}$ & .812 & .809 & 1.82477 \\
\hline
\end{tabular}

a. Predictors: (Constant), $\mathrm{X}$

Source: Data processed (SPSS, 23.0)

Based on table 2, it is known that Work-Life Balance at the Bima Regency Social Service has good grades. That is, the balance of life and work of the employees are well balanced in terms of the balance of time, the balance of involvement and the balance of satisfaction. This can be seen from the score of respondents' answers with a correlation value of 0.901 , this shows that the relationship between the variable Work Life Balance with the variable Job satisfaction is at a level of strong relationships that fall into either category.

\section{Coefficient of Determination}

The result of the coefficient of determination test is $\mathrm{R}$ square with a 4.2 value of 0.814 which means the contribution of Work-Life Balance to job satisfaction is $81.4 \%$ and the remaining $18.6 \%$ is influenced by other variables not examined in this study. Thus this study shows that there is a good contribution Work-Life Balance to the Bima Regency Social Service employee job satisfaction which means the better Work-Life Balance for employees will increase employee job satisfaction.

\section{Hypothesis Testing (t-Test)}

The t-test results (significant test) in table 1 show that the $t$ test between $X$ (Work-life balance) and Y (Job satisfaction) shows $\mathrm{t}$-count $=15,827$. While t table $(\alpha=0.05 ; \mathrm{db}$ residual $=58)$ is 2.002. Because $t$-count $>t$-table is $15.827>2.002$ or sigs $t$ value $(0,000)<\alpha=$ 0.05 , the effect of variable $\mathrm{X}$ (Work-life balance) on variable $\mathrm{Y}$ (job satisfaction) is significant. This means that $\mathrm{H} 2$ is rejected and $\mathrm{H} 1$ is accepted so it can be concluded that employee job satisfaction can be significantly influenced by work-life balance or by increasing work-life balance, 
employee job satisfaction will experience a significant increase.

\section{DISCUSSION}

The purpose of this paper is to determine the importance of work-life balance in encouraging employee job satisfaction at the Bima Regency Social Service. Based on the results of the analysis using SPSS version 23, the validity test of Work-life Balance variables and employee morale of all items are declared valid because the value of the first item to the last item, where r-count has a value greater than r-table then all the questions can be used in research. Worklife Balance variable reliability test and work satisfaction variable can be seen that the value of Cronbach's Alpha is higher than the minimum value of Cronbach's Alpha. For that the research instrument can be said to be reliable. From the results of the determinant coefficient calculations, it can be seen that the work-life balance has a positive relationship with job satisfaction.

Based on a simple linear regression test, it is known that the balance of time, the balance of involvement and the balance of satisfaction which are indicators of the work-life balance variable indicate a positive regression coefficient, it indicates a positive direction or a direct relationship of the Work-life Balance (X) variable with employee satisfaction (Y). Based on the results of the $t$ test showed that there is a significant influence between Work-life Balance on job satisfaction at the Social Service Office of Bima Regency. This is in line with the results of research from Diah Lailatul Qodrizana and Mochammad Al Musadieq (2015) which states based on the results of hypothesis testing the work-life balance variable represented by indicators of time balance, balance of involvement and balance of satisfaction significantly influence work satisfaction.

When related to the theoretical basis according to the work-life balance (work life balance) itself is how a person is able to balance work demands with personal and family needs (Ramadhani, 2013). Creating and maintaining employee job satisfaction is an effort that can have a major impact on the survival of an organization. This is because, satisfied employees bring a positive influence on the organization. Thus it can be seen the relationship between work-life balance and job satisfaction. Where job satisfaction can actually be achieved when the organization supports the creation of work-life balance.

\section{CONCLUSION}

Based on the results of statistical analysis, it is known that work-life balance has a significant effect on employee job satisfaction at the Bima Regency Social Service. So it can be concluded that the application of work-life balance of employees by paying attention to the balance of time, the balance of involvement and the balance of satisfaction is very important, because it 
can encourage increased employee job satisfaction.

\section{SUGGESTION}

It is expected that the Bima Regency Social Service can maintain work-life balance for employees, because the work-life balance variable affects employee job satisfaction including paying attention to time balance, balance of employee involvement and balance of employee satisfaction. By considering these things, it can improve employee performance with a balance of employee satisfaction.

\section{REFERENCESS}

Diah Lailatul Qodrizana, 2015. Pengaruh Work-Life Balance Terhadap Kepuasan Kerja (Studi Pada Pegawai Perempuan Yayasan Insan Permata Tunggulwulung Kota Malang). Jurnal Administrasi Bisnis (JAB)|Vol. 60 No. 1 Juli 2018.

Fenia Annamaria Rondonuwu, et al, 2018.

Pengaruh Work-life Balance Terhadap Kepuasan Kerja

Karyawan Pada Hotel Sintesa Peninsula Manad. Jurnal Administrasi Bisnis Vol. 7. NO. 2, 2018

Fisher, G., Bulger, C., \& Smith, C. 2011. Beyond Work and Family: A Measure of Work/Nonwork Interference and Enhancement. Journal of Occupational Health Psychology. 14 (4), 441-456.
I Made, D, Ganapathi, 2017. Pengaruh Work-Life Balance Terhadap Kepuasan Kerja Pegawai (Studi Pada PT. Bio Farma Persero). $e$ Proceeding of Management : Vol.3, No.1

Lockwood, N. R. 2013. Work/Life Balance: Challenges and Solutions. Research Quaterly, 1-10 Malayu S.P. Hasibuan, 2015. Manajemen Sumber Daya Manusia. Jakarta: PT. Bumi Aksara.

Moedy, Dinda Mega Rulita. 2013. Analisis

Work-Life Balance, Keinginan Untuk Meninggalkan Organisasi, Kepenatan (Burnout) Dan Kepuasan Kerja Pada Dosen Universitas Atma Jaya Yogyakarta. E-Journal Universitas Atma Jaya Yogyakarta.

Purwati, P. D. 2016. Pengaruh Keseimbangan Kehidupan Kerja (Work-Life Balance) Terhadap Beban Kerja (Work Load) Divisi Penjualan di PT. Ulam Tiba Halim (MARIMAS) Cabang Sidoarjo. Skripsi Universitas Islam Negeri Maulana Malik Ibrahim Malang.

Ramadhani, Malika. 2013. Analisis Pengaruh Keseimbangan

Kehidupan Kerja Terhadap Kesuksesan Karir (Studi pada Pegawai PT. Asuransi Jiwa Generali Indonesia). Jurnal FEB Universitas Brawijaya Malang. Schermerhon, 2012. Work - Life Balance and Job Satisfaction Among Doctors in Pakistan. South Asian 
JSM, Volume 2, Number 2, July 2020

P-ISSN : 2655-3651

E-ISSN : 2656-0435

Journal of Management, 17 (2): 112-123.

Sutrisno, Edy. 2015. Manajemen Sumber Daya Manusia (Cetakan ke tujuh). Jakarta: Kencana Prenada Media
Group.Fapohunda, dkk. 2014. Perilaku Organisasi dan Psikologi Personalia. Jakarta: PT. Rineka Cipta. 